\title{
The significance of the Sun, Moon and celestial bodies to societies in the Carpathian basin during the Bronze Age
}

\author{
Emília Pásztor \\ Dunaföldvar, Sohaz. u. 4., 7020 Hungary \\ email: emipasztor@freemail.hu
}

\begin{abstract}
Celestial events often exerted a great or even decisive influence on the life of ancient communities. They may provide some of the foundations on which an understanding of the deeper meaning of mythologies, religious systems and even folk tales can be based. These influences are reflected and may be detected in the archaeological material as well. There is good evidence that celestial (especially solar and perhaps lunar) phenomena played a particularly important rôle in the worldview of prehistoric Europe. To reveal the social and ideational significance of concepts relating to the celestial bodies in the prehistory of the Carpathian Basin, complex investigations on orientations of houses and graves, prestige archaeological finds and iconography have been accomplished. The results indicate ideological and/or social changes, which developed into a likely organized ideological system in large part of Central Europe including the Carpathian Basin by the Late Bronze Age. It might also be the first period in prehistory when people became really interested in celestial phenomena.
\end{abstract}

Keywords. Prehistory, Carpathian Basin, sky lore, orientation, celestial symbols, divinization of elite

\section{Sources to study the impact of celestial phenomena on prehistoric societies}

There are four main sources:

(a) Astronomical: what kind of phenomena can be observed by naked eye in the Carpathian Basin?

(b) Historical: what conclusion can be drawn relating to the Carpathian Basin from the historical records on the history of astronomy?

(c) Ethnographical: folk astronomy and its use in Central Europe;

(d) Archaeological: the possible archaeoastronomical material of the Carpathian Basin.

We briefly review them here in turn.

\section{Celestial phenomena and bodies visible by naked eyes in the Carpathian Basin}

A significant feature of folk astronomy is that it involves not only astronomical but meteorological events as well. The visibility of celestial bodies and phenomena is determined by several factors. The geographical location (especially latitude) and topography determine what kind of phenomena and bodies can be observed but the climate and the actual weather also have influence on it. The Carpathian Basin lies between $45^{\circ}$ and $49^{\circ}$ northern latitude and surrounded by high mountains of the Carpathians, the Transylvanian Alps and the Alps. Two big rivers divide the basin into a hilly and an open country. The visible astronomical phenomena of the Carpathian Basin involve the regular 
motions of the celestial bodies such as the Sun, the Moon, Venus and perhaps Jupiter; their special positions to each other; the apparent motions of the constellations; the bright stars and the appearance of comets and "falling stars" etc. The visible typical atmospheric phenomena (Hegedüs 2004) cover the changing colour and pattern of the sky during the different seasons, the thunder storms and lightning, the blizzard, the golden and purple arcs at sunset and sunrise at the horizon, etc. besides the different aerial formations caused by the reflection, dispersion, diffusion and refraction of light.

In the Carpathian Basin the natural environment already had a significant change during the Neolithic Period. The wooded areas decreased and the cultivated lands considerably enlarged. Another significant ecological alteration happened in the Middle Bronze Age from about $1500 \mathrm{BC}$. The landscape became similar to the present one. Expansion of inhabited areas, grazing and arable lands characterized the scenery. The climate was also similar to the present one (Sümegi \& Töröcsik 2007), thus the (almost) same celestial phenomena as in our days could also have been observed in the Bronze Age.

\section{Deduction from historical sources}

Studies of the origin of constellations reveal how long ago people became interested in the starry sky. The star groups of Bears with Boötes are argued to be created before 10,000 BCE. The zodiacal groups with some Mesopotamian constellations are argued to be taken over around 500 BCE (Rogers 1998a,b), although there is also an assumption on the Indo-European origin of the zodiacal constellations (Gurshtein 2005). The Perseus group is of Greek origin, from 1250-480 BCE (Wilk 2000). There are however, groups showing non-Mesopotamian and non-Greek origin. The serpent like monsters and giants might have been projected onto the sky vault in 4th-2nd millennia BCE (Rogers 1998a,b; Frank and Bengoa 2001). There are groups of stars which are known to most cultures for their distinctive shapes, such as the Great Bear, Orion and the Milky Way. All these prove that human imagination has clustered virtual groups of stars since early times. Thus it is reasonable to suppose that star groups might also have been created in the Carpathian Basin during the Bronze Age (Pásztor and Roslund 2007).

\section{Ethnographical sources}

Investigation of traditional societies' folk astronomy can help a lot with recognising the characteristic features of traditional sky lore. Even inside the Carpathian Basin there is difference in the interest and cognition of sky between the different regions. The celestial knowledge of people living on the Great Plain and the Hungarian steppe called Hortobágy is richer and more colourful (Zsigmond 1999). The essential elements and their functions in ethno-astronomy of the Carpathian Basin are the following (Pásztor 2011a):

- Atmospheric phenomena: weather lore/magic, forecast, myths;

- Stars: visualisation of historical and religious experiences; bearings on land; time counting for work, festivals; weather forecast

- Star lore (constellations) is much influenced by the activity for living (Amades 1994): ploughmen: farming -sowing, harvest; fishermen: navigation at sea; shepherds: driving animals out/in;

- Sun: orientation of houses, rarely settlement, time counting, weather lore, magic; Perfect knowledge its daily and annual motion - always positive impact; Celebration of summer and especially winter solstice may go back far in the past;

- Moon: time counting/calendar, weather forecast/magic; waxing/waning Moon: wiz$\operatorname{ardry/magic.~}$ 
Anthropological research also proves that celestial lore is applied to different use in traditional societies:

- Common/everyday application shared by everybody: weather/time lore, orientation, etc. (Szabó 1990);

- Special occasions' application, the necessary knowledge is shared by not everybody (Chamberlain 1982; MacDonald 1998): in hard times, fateful events, turning points, regular rituals, etc.

The description of traditional sky lore is however, often not complete. There are phenomena missing from the conclusions. The main reason of it is not the un-interest of the community investigated but the anthropologists/ethnographers have no astronomical education, thus no questions are raised which cover all celestial phenomena.

\section{Archaeological sources}

When lacking megalithic monuments and rock art, archaeoastronomical investigations should rely upon the archaeological material available. There are no remains of temples or special sacral buildings in the Carpathian Basin during the Bronze Age. The sacral deposits do not show the existence even of a possible regularly used sacral area either. Their finding locations however, indicate specific world view (Pásztor 2010b). As the archaeological finds show the presence of no hierarchical or organised religion, the belief system might have been similar to the traditional folk beliefs, which considered the surrounding world as the natural unification of animate and inanimate nature (Pásztor 2011b). This argument however, is not valid for the whole prehistory of the Carpathian Basin.

In the late Neolithic Period, the Lengyel cultural complex raised circular earthworks which served as common communal-sacral place for several settlements. The investigation of these causewayed enclosures proves that they were built according to a common set of geometrical and astronomical rules (Barna \& Pásztor 2010; Pásztor and Barna 2011). The actual direction of the rising Sun offers a good interpretation for the orientation of the regular ground plans with the symmetrically arranged causeways. The investigation of more than 50 roundels of Hungary, Low Austria, Moravia and South Slovakia supports this argument. Beside the orientation other archaeological material and characteristic features also support a possible Sun worship of the farming community during the late Neolithic Period (Pásztor, Barna and Roslund 2008).

\subsection{Orientation of houses}

The study of the orientation of houses of the Bronze Age is not so promising as of a sacral monument. Positioning a house is mostly influenced by environmental factors such as solar radiation, prevailing wind or necessity for natural light. Archaeological and ethnographical research however, argues the significance of non-environmental factors as well (Coudart 1998; Bereznai 1999). Case studies support intention in orientation. 13 unique houses of a settlement of the early Bronze Age Bell Beaker culture are aligned with midwinter Sun. At winter solstice for about 10-12 days the sunrays penetrate into the houses through the gables at about 9 am (Pásztor 2005). A Late Bronze Age settlement of 60 houses at the Dunakeszi-Székesdülő site is also a good example for intentional orientation. The longer axes of the houses show a high correlation with the North-South direction. The same can be argued for the main entrances of the houses in connection with the East direction as the main doorways were generally found on the eastern side of the houses, close to its southern end. The aligning with the southern direction (for the main axis) or the rising Sun (for the main entrances) might have had strong symbolical 


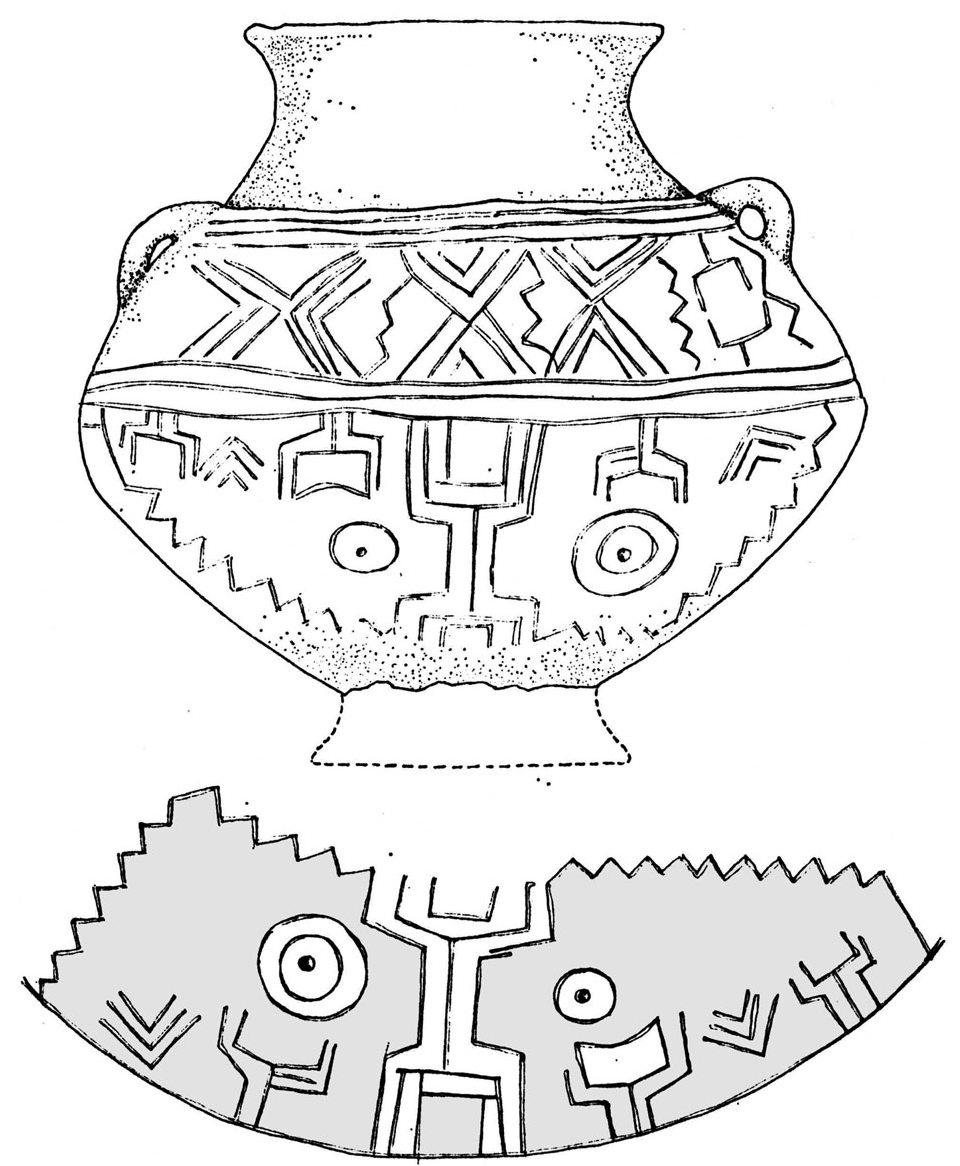

Figure 1. Hanging vessel decorated with possible Sun and Moon symbols, stray find, Budapest - Pannonhalmi út, Nagyrév culture, 22-18th century BCE (Schreiber 1984).

meaning including the sun motion. If the houses were oriented at all, their main entrances preferred to be aligned with the due east, and/or the long axes with the due North-South (Pásztor 2009a). Although the orientation of the entrances is likely astronomical but that of the main axis is rather cosmological in connection to the belief system.

Investigating the orientations of other houses available from published material, it can be concluded that the dispersion is often low, which supports intentional orientation, the dispersion at a site with different cultures is often lower than at different sites of a cultural group, clusters of certain directions can be detected and a slight preference of N$\mathrm{S} / \mathrm{S}-\mathrm{N}$ can be observed. This direction has, however, more in common with cosmological beliefs than astronomy.

\subsection{Orientation of graves}

The conclusions after examining several Bronze Age cemeteries are the following (Pásztor 2009b):

- No general preference to a certain direction even in a cultural group;

- Different cemeteries of a cultural group might have different orientations;

- No sense of average orientation for the whole period;

- A 'cultural' group should be investigated in its own context. 

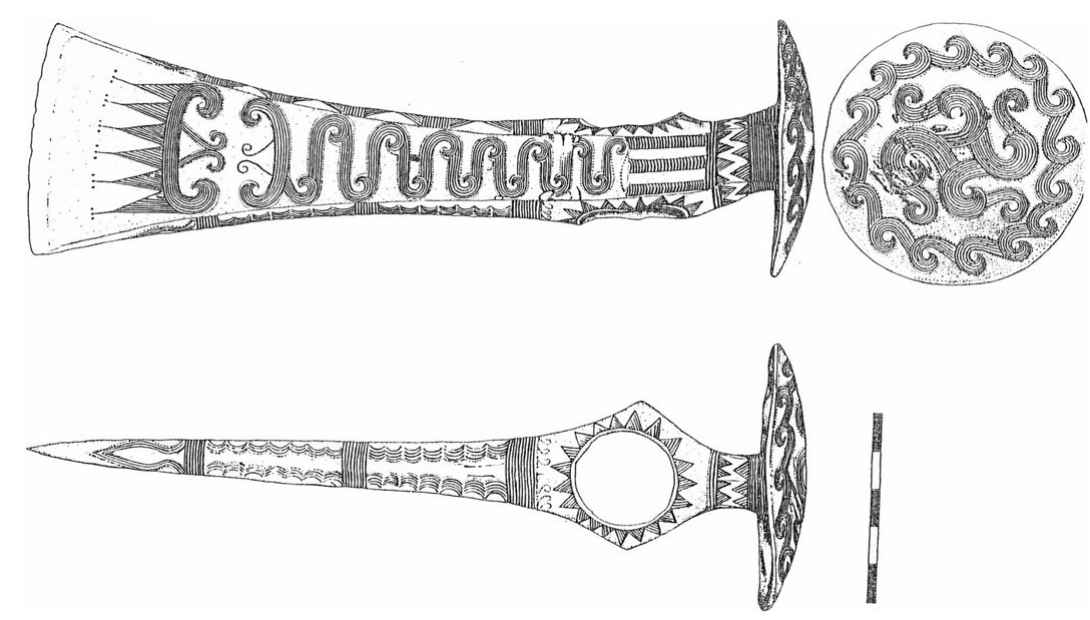

Figure 2. A prestige bronze axe richly decorated with Sun and clouds symbols. Hajdúsámson hoard, 17-14th century BCE, Hungary (Kóvacs 1977).

\subsection{Celestial/Cosmological symbols}

Bronze Age mythology is argued to focus on the Sun. Many prestige artefacts bear symbols which are argued sun symbols. Concentric circles assumed also Sun (or Moon?) symbols are common elements of rock art of Atlantic Europe. Although there are no rock carvings or paintings in the Carpathian Basin, abstract symbols richly cover the archaeological finds including many prestige artefacts. The study of 'iconography' means to investigate how ancient people represented their ideological, political, religious and/or cosmological ideas in their art. The analyses of visual representation on artefacts are essential, however, it is often difficult to decide whether the decorations were applied intentionally and involved a shared knowledge with the whole community or they were only decoration motifs (Renfrew and Bahn 2004). The results of the investigations carried out on archaeological finds of the Carpathian Basin until now are the following:

- The possible depictions of celestial bodies and phenomena are symbolical rather than real;

- Generally it is better to speak about celestial/cosmological symbols rather than solar or lunar ones;

- The symbols cannot be identified or connected clearly with celestial bodies, although the symbols of the Sun, Moon and planet Venus might be found among the symbols relying upon early Mesopotamian analogies (Pásztor 2009d);

- The number of celestial symbols on finds is growing during the Bronze Age;

- Prestige finds of the second half of the Bronze Age were very often decorated by celestial/cosmological symbols;

- Archaeological cultures, regions, periods cannot mix as they can make false conclusions.

Why did all these universal cosmological symbols become of interest and importance? There is almost a universal belief in a celestial divine being that created the universe and guarantees the fecundity of the earth (Eliade 1958). Although animism seems to be the ruling mythological background in the Bronze Age, a different belief system, the Proto-Indo-European one, must also have co-existed in the Carpathian Basin by then. Their possible presence in the central Danube area can be put in the Bronze Age or rather earlier (Adams \& Otte 1999; Gimbutas 1997; Renfrew 1987). Until we may say 
that the sky gods of the Uralo-Altaic tribes have kept their primordial characteristics better than others, this is generally speaking not true for the Proto-Indo-European sky divinities. In time many of these sky gods became 'specialised', turned into storm or fertility gods. This process is largely explained by the passive nature of the sky gods and their tendency to give place those who are more concrete and more directly involved in the daily life of humans (Eliade 1958). This fairly complex evolution might have been in process during the Bronze Age as there are artefacts, especially among the prestige ones, which might be connected with the Proto-Indo-European mythology. This alteration in belief system might have been contemporary with the social changes in the Bronze Age: the development of regional political control, a need for the emerging élite to legitimize structures of dominance and power. To do it in an effective way was to use a mythological and cosmological pattern in which a divinization of a part of mankind -the élite- was believed to be 'natural' (Larsson 1999). The chiefly power was assumed to be the gift of the gods like for the Egyptian pharaohs or Minoan kings. The bronze and gold finds became the visible sign of supremacy. A cosmology and an ideology of the ruling élite were formed in Central Europe. The spread of this ideology was linked to the spread of the bronze metalworking technology (Larsson 1999). They acted as cosmic symbols as well as royal and chiefly regalia in different parts of Europe but not as the signs of a general Bronze Age sun cult.

\section{Conclusions}

There is good evidence that celestial phenomena played a particularly important rôle in the worldview of prehistoric Carpathian Basin. People of the Bronze Age must have been familiar with the daily/yearly motion of the sun and perhaps there is a slight reference to the observation of the southernmost position of the sun according to the house orientations, however, it has been proved that orientation solely is not enough to offer satisfactory information about prehistoric sky lore. During the Bronze Age the increasing use of special symbols assumed to be solar and lunar or rather cosmological ones are well known and easily discernible on different types of archaeological artefacts. Complex investigations have revealed more about the possible sky lore and its impact. The results indicate social changes accompanied with ideological changes involving more interest in sky, from the Middle Bronze Age on. Indirect deduction from historical and ethnographical sources can, however, argue that the Bronze Age sky lore also involve the knowledge of the regular change of moon phases for possible magic purposes or initial calendar, the creation and use of constellations and observation of certain atmospheric phenomena which was necessary for weather lore and maybe for magic. Although there are finds from other parts of Europe with possible atmospheric phenomena such as rainbow, or sky colour (Pásztor and Roslund 2007), but such finds from the Carpathian Basin have not been discovered yet. To sum up it can be stated that the astronomical knowledge of Bronze Age Carpathian Basin was like folk astronomy and seemingly hardly more than the Neolithic. The celestial bodies and phenomena's impact might however, have been more decisive than ever before.

\section{References}

Adams, J. \& Otte, M. 1999, Current Anthropology, 40, 73

Amades, J. 1994. Des étoiles aux plantes: petite cosmogonie catalane (Carcassone: GARAE/HESIODE; Toulouse: Presses Universitaires du Mirail) 
Barna, J. P. \& Pásztor, E. 2010, in Proceedings of the XV World Congress UISPP, Session C68 (Part I): Monumental Questions: Prehistoric Megaliths, Mounds, and Enclosures, D. Calado, M. Baldia and M. Boulanger (eds) (Oxford: BAR S2122), p. 119

Bereznai, Z. 1999, Cumania, 16, 115

Chamberlain, V. D. 1982, When Stars came down to Earth. Cosmology of the Skidi Pawnee Indians of North America (Los Altos: Ballena Press)

Coudart, A. 1998, Architecture et société néolithique: l'unité et la variance de la maison danubienne (Paris: Editions de la Maison des Sciences de l'Homme)

Eliade, M. 1958, Patterns in Comparative Religion (London: Sheed and Ward)

Endrődi, A. \& Pásztor, E. 2006, Archaeológiai Értesítő, 131, 7

Frank, M. R. \& Bengoa, J. A. 2001, in Astronomy, Cosmology and Landscape, C. Ruggles, F. Prendergast \& T. Ray (eds) (Leicester: Ocarina Books), p. 15

Gimbutas, M. 1997, The Kurgan Culture and the Indo-Europeanization of Europe. Selected articles from 1952-1993 M. R. Dexter and K. Jones-Bley (eds) Journal of Indo-European Studies Monograph No. 18 (Washington DC: Institute for the Study of Man)

Gurshtein, A. 2005, Journal of Indo-European Studies, 33, 103

Hegedüs, T. 2004, Természet Világa, 135, 14

Krupp, E. C. 1997, Skywatchers, Shamans, and Kings: Astronomy and Archaeology of Power (New York: John Wiley and Sons)

Kóvacs, T. 1977, Bronzkor Magyarországon (Budapest: Corvina)

Larsson, T. B. 1999, in Communication in Bronze Age Europe, Transactions of the Bronze Age Symposium in Tanumstrand, Bohuslan, Sweden, September 7-10, 1995, C. Orrling (ed) (The Museum of National Antiquities, Stockh. Studies, 9) (Stockholm: Statens Historiska Museum), p. 9

MacDonald, J. 1998, The Arctic sky: Inuit astronomy, star lore, and legend (Toronto: Royal Ontario Museum and Nunavut Research Institute)

Pásztor, E. 2005, in Lights and Shadows in Cultural Astronomy, M. P. Zedda and J. A. Belmonte (eds) (Isili: Associazione Archaeofila Sarda), p. 116

Pásztor, E. 2009a, in Landscape in Mind: Dialogue on Space between Anthropology and Archaeology, G. Dimitriadis (ed) (Oxford: BAR S2003)

Pásztor, E. 2009b, in Cognitive Archaeology as Symbolic Archaeology, F. Coimbra and G. Dimitriadis (eds) (Oxford: BAR IS 1737), p. 13

Pásztor, E. 2009c, in Cosmology Across Cultures, ASP Conference Series, Vol. 409, J. A. RubiñoMartín, J. A. Belmonte, F. Prada, and A. Alberdi (eds) (San Francisco: Astronomical Society of the Pacific), p. 457

Pásztor, E. 2009d, in MOMOSZ VI. Őskoros konferencia, G. Ilon (ed) (Szombathelyi: KÖSZ/Vas Megyei Múzeumok Igazgatósága), p. 22

Pásztor, E. 2010b, in Csányi Marietta kőszőntése, G. Kaposvári and J. Tárnoki (eds) (Tisicum: Szolnok), p. 172

Pásztor, E. 2011a, in Essays to the honour of János Makkay, M. Fekete (ed) (Pécs: University Press), in press

Pásztor, E. 2011b, in Archaeology and Experimenting Spirituality, D. Gheorghiu \& A. Peatfield (eds) (Oxford: BAR IS), in press

Pásztor, E. \& Barna, J. P. 2011, in in Place As Material Culture, Objects, Geographies and the Construction of Time, D. Gheorghiu and G. Nash (eds) (Newcastle upon Tyne: Cambridge Scholars Publishing), in press

Pásztor, E., Barna, J. P., \& Roslund, C. 2008, Antiquity, 82, 910

Pásztor, E. and Roslund, C. 2007, Antiquity, 81, 267

Renfrew, C. 1987, The Archaeology and Language: the Puzzle of Indo-European Origins (Cambridge: Cambridge University Press)

Renfrew, C. \& Bahn, P. 2004, Archaeology: theories, methods and practice (London: Thames and Hudson)

Rogers, J. H. 1998a, Journal of the British Astronomical Association, 108, 9

Rogers, J. H. 1998b, Journal of the British Astronomical Association, 108, 79 
Schreiber, R. 1984, Archaeologiai Értesitő, 111, 3

Sümegi, P. \& Töröcsik, T. 2007, Természet Világa, 138, 7

Szabó, L. 1990, in Népszokás, néphit, népi vallásosság, T. Dőmőtőr and M. Hoppál (eds) (Budapest: Akadémia Kiadó), p. 725

Wilk, S. R. 2000, Medusa: Solving the mystery of the Gorgon (Oxford: Oxford University Press)

Zsigmond G. 1999, Égitest és néphagyomány (Csíkszereda: Pallas-Akadémia Kőnyvkiadó) 